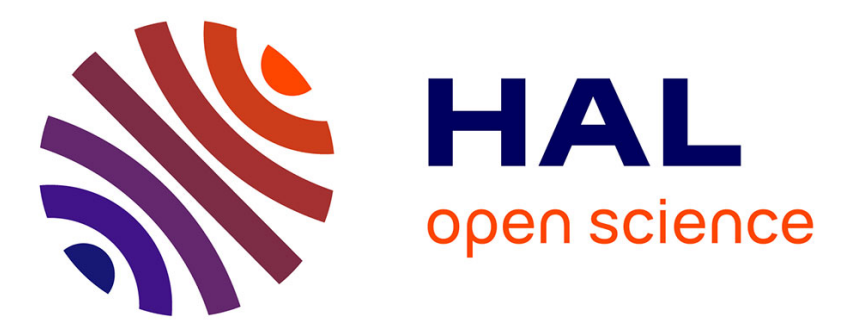

\title{
Impact of a synthetic leachate on permittivity of GCLs measured by filter press and oedopermeameter tests
}

\author{
S. Rosin-Paumier, N. Touze-Foltz, A. Pantet
}

\section{To cite this version:}

S. Rosin-Paumier, N. Touze-Foltz, A. Pantet. Impact of a synthetic leachate on permittivity of GCLs measured by filter press and oedopermeameter tests. Geotextiles and Geomembranes, 2011, 29 (3), pp.211 - 221. 10.1016/j.geotexmem.2010.11.001 . hal-01717750

\author{
HAL Id: hal-01717750 \\ https://hal.science/hal-01717750
}

Submitted on 18 Jun 2018

HAL is a multi-disciplinary open access archive for the deposit and dissemination of scientific research documents, whether they are published or not. The documents may come from teaching and research institutions in France or abroad, or from public or private research centers.
L'archive ouverte pluridisciplinaire HAL, est destinée au dépôt et à la diffusion de documents scientifiques de niveau recherche, publiés ou non, émanant des établissements d'enseignement et de recherche français ou étrangers, des laboratoires publics ou privés. 
Impact of a synthetic leachate on permittivity of GCLs measured by filter press and oedopermeameter tests

$\underline{\text { S. Rosin-Paumier }}{ }^{1}$, N. Touze-Foltz ${ }^{1}$, A. Pantet $^{2}$

${ }^{1}$ Hydrosystems and Bioprocesses Research Unit, Cemagref, B.P. 44, 92163 Antony Cedex.

${ }^{2}$ Laboratoire d'Etudes Aérodynamiques (LEA), Université de Poitiers, ENSMA, CNRS, Téléport 2, Boulevard Marie et Pierre Curie, BP 30179, 86962 Futuroscope Chasseneuil, France.

Sandrine ROSIN-PAUMIER

Phone: +33140966214

Fax: +33140966270

*E-mail of the corresponding author: nathalie.touze@ cemagref.fr

\section{ABSTRACT}

Geosynthetic clay liners (GCLs) are used in landfill liner applications due primarily to their low hydraulic conductivity to water. The low hydraulic conductivity of GCLs comes from the structure of the clay in the bentonite. However, the interaction between clay and aggressive liquids may alter the structure of the clay and, thus, result in an increase in the hydraulic conductivity of the GCL. This paper presents the results of a project aimed at evaluating the impact of a synthetic leachate on the structure of four different bentonites used in the manufacturing of GCLs. The preparation of bentonite dispersions increased the interaction between the bentonites and the various liquids. The hydraulic properties of the dispersions also were tested using filter press tests to obtain flow curves. Results of these tests were correlated with the cationic concentration, electrical conductivity and $\mathrm{pH}$ of the 
dispersions, swell indexes of the bentonite extracted from the GCLs, and permittivities of the intact GCLs determined in oedopermeameter tests. The results showed that one bentonite was more sensitive to the synthetic leachate than the other bentonites. For example, the permittivities of the more sensitive bentonite based on the oedopermeameter tests and filter press tests were respectively $2.11 \times 10^{-8} \mathrm{~s}^{-1}$ and $5.6 \times 10^{-8} \mathrm{~s}^{-1}$, whereas the permittivities for other bentonites, including a natural sodium bentonite and two sodium activated calcium bentonites, were respectively 5.7 to $6.5 \times 10^{-9} \mathrm{~s}^{-1}$ and 3.2 to $3.5 \times 10^{-8} \mathrm{~s}^{-1}$. The filter press test served as a quick and easy-to-use test to compare the performance of the various bentonites in containing a given liquid. However, the oedopermeameter test or direct permeation test is preferable to filter press tests or fluid loss tests for evaluating the long-term impact of a liquid on a bentonite.

Keywords: bentonite, cation exchange, permittivity, synthetic leachate.

\section{INTRODUCTION}

Geosynthetic clay liners (GCLs) generally consist of a layer of granular or powdered bentonite sandwiched between two geotextiles, linked by needle punching or stitch bonding. Bentonite has been widely studied, and consists of a mixture of minerals, with the predominant mineral being smectite (van Olphen, 1977; Patterson and Murray, 1983). However, the quality of bentonites used in GCLs for landfill applications may vary widely.

The smectite mineral imparts to the bentonite its swelling properties and its low hydraulic conductivity. For landfill bottom liner applications in France, sodium bentonite is recommended for use in GCLs, meaning that sodium ions are the predominant exchangeable cations of the bentonite (MEEDDAT, 2008). The existence of sodium as the exchangeable cation may be the result of natural geological processes, as typically the case for Wyoming 
sodium bentonites, or the result of an activation process whereby naturally occurring calcium bentonite is mixed with soda ash to force sodium-for-calcium cation exchange. These latter bentonites are often called sodium-activated calcium bentonites.

GCLs have gained widespread popularity as a substitute or as a reinforcement for compacted clay liners in cover systems and composite landfill bottom liner systems (Bouazza, 2002; Touze-Foltz et al., 2008). In composite bottom liner systems where a geomembrane overlying the GCL is damaged, seepage of municipal solid waste (MSW) leachate can occur through the defect, at the interface between the geomembrane and the GCL and subsequently through the GCL. As MSW leachate usually contains cations, cation exchange can occur in the GCL upon exposure of the GCL to the leachate (Egloffstein, 2001).

Numerous laboratory studies have focused on quantifying the hydraulic conductivity of GCLs in contact with various types of permeant liquids containing cations (Alther et al., 1985; Shan and Daniel, 1991; Egloffstein, 1997; Petrov and Rowe, 1997; Petrov et al., 1997 a,b; Quaranta et al., 1997; Ruhl and Daniel, 1997; Shackelford et al., 2000; Egloffstein, 2001; Jo et al., 2001; Vasko et al., 2001; Ashmawy et al., 2002; Shan and Lai, 2002; Kolstad et al., 2004a,b; Lee et al., 2005; Guyonnet et al., 2005; Jo et al., 2005; Benson et al., 2008; Katsumi et al., 2008a,b; Rauen et al., 2008; Touze Foltz et al., 2008; Guyonnet et al., 2009; Johns and Shamrock 2009; Shackelford et al. 2010). Hydraulic conductivity tests were conducted either with flexible wall permeameters (ASTM, 2008, 2003) or rigid-wall permeameters such as the oedopermeameters according to NF P 84-705 (AFNOR, 2008). Recommendations for the use of GCLs cases where they are in contact with leachate are provided in most of these studies. For example, pre-swelling of the GCL with water of low electrolyte concentration and providing a minimal thickness of confining soil over GCLs has been recommended. Also, when the electrical conductivity (EC) of the permeant liquid is higher than $1000 \mu \mathrm{S} / \mathrm{cm}$, Egloffstein et al. (2002) recommended that the concentrations of $\mathrm{Ca}^{2+}, \mathrm{Mg}^{2+}$ and $\mathrm{Fe}^{2+}$ in the 
permeant liquid be determined as an indicator of the negative impact of the liquid on the permittivity of bentonite layers. However, generalisation of these recommendations is difficult due to the variety of GCLs and liquids tested. Also, permeability tests can be timeconsuming and expensive. Construction engineers need tests methods that result in rapid and cost-effective information to check whether a given product is suitable for a given application. According to Day (1994) and von Maubeuge (2002), the fluid loss test is a quick qualitative test that provides an indication of the ability of the bentonite to work effectively in a GCL. However, this index test (ASTM D5891) only furnishes a fluid loss volume at the end of the test, which is inadequate to determine the permittivity of the cake formed during the test. In contrast, the effluent from a filter press test, which is similar to the fluid loss test (ASTM, 2009), is collected throughout the test to acquire a filtration curve that can be used to calculate the permittivity of the bentonite cake formed during testing. For example, RosinPaumier et al. (2010) compared the permittivities obtained from filter press tests and oedopermeametric tests on eight bentonites dispersed in $10^{-3} \mathrm{M} \mathrm{NaCl}_{2}$ Rosin-Paumier et al. (2010) -concluded that the filter press tests may provide a relatively quick (e.g., within a few hours) indication of the long-term results of the oedopermeameter tests for the contact of bentonite with $10^{-3} \mathrm{M} \mathrm{NaCl}$.

Various solutions have been proposed in the literature to calculate the permittivity of the cake (Henry et al., 1998; Kelessidis et al., 2006; Pantet and Monnet, 2007; Chung and Daniel, 2008). The procedure of Pantet and Monnet (2007) was chosen in this study because this procedure maintains a saturated cake, which resembles the condition of the bentonite encountered in the oedopermeameter tests and in landfill bottom liner applications.

Thus, the first objective of this study was to investigate the possible extension of the use of filter press tests to reveal a potential impact of an aggressive liquid in the form of a synthetic leachate on four bentonites. Some filter press tests also were performed using 
dilutions of the synthetic leachate to provide a range of liquids more or less aggressive to the bentonites. The second objective of this study was to test the ability of filter press tests to provide within only a few hours an indication of the long-term results based on oedopermeameter tests for the contact of bentonite with leachate. The permittivities of four GCLs in contact with the aggressive synthetic leachate were determined by filter press tests and oedopermeametric tests. The interaction between the bentonite and the liquid for each test was studied by chemical analysis.

\section{MATERIALS AND METHODS}

\subsection{Bentonites}

Four GCLs were selected among those supplied by three of the primary GCL suppliers to the European market. The products were selected to be representative of GCLs used in bottom liner applications. LX1 was a stitch-bounded GCL consisting of a layer of bentonite and a nonwoven geotextile encapsulated between two woven geotextiles with masses per unit area close to $110 \mathrm{~g} / \mathrm{m}^{2}$. LX2, LX5 and LX7 were needle-punched GCLs consisting of a layer of bentonite encapsulated between a non-woven $\left(220 \mathrm{~g} / \mathrm{m}^{2}\right)$ and a woven geotextile (110 $\mathrm{g} / \mathrm{m}^{2}$ ). One GCL, (LX2) contained $5 \mathrm{~kg} / \mathrm{m}^{2}$ of natural sodium bentonite, whereas the other three GCLs (LX1, LX5, LX7) contained $5 \mathrm{~kg} / \mathrm{m}^{2}$ of sodium-activated calcium bentonites. These four bentonites were also studied by Guyonnet et al. (2009), Paumier et al. (2009) and Rosin-Paumier et al. (2010), and the mineralogical and chemical properties of the bentonites as determined by Guyonnet et al. (2009) are summarised in Table 1.

\subsection{Synthetic leachates}


Composition of the synthetic leachate (SL) was determined by Guyonnet et al. (2009) and was selected based on a review of leachate compositions in France (SITA-FD, pers. comm.) and literature data (Kjeldsen et al., 2002), with the objective of obtaining a leachate composition representative of a "young" leachate in terms of inorganics, i.e., rich in divalent cations and hence potentially "aggressive" with respect to a sodium bentonite. Tab. 2 shows the salt concentrations used to generate the synthetic leachate. The resulting measured composition of the SL is shown in Tab. 3.

The resulting ratio of monovalent-to-divalent cations, or RMD (Eq.1), of the SL was $0.43 \mathrm{mM}^{1 / 2}$, where RMD $\left(\mathrm{mM}^{1 / 2}\right)$ is defined as per Kolstad et al. (2004a)

$$
R M D=\frac{M_{M}}{\sqrt{M_{D}}}
$$

where $M_{M}$ is the total molarity of the monovalent cations in the solution and $M_{D}$ is the total molarity of the divalent (or polyvalent) cations. RMD is zero for solutions devoid of monovalent cations, and is infinite for solutions containing only monovalent cations.

Three oedopermeameter tests were performed with the SL used as the permeant liquid. However, for filter press tests, both the pure (undiluted) SL solution and solutions of the pure SL diluted with deionised water (DW: $\mathrm{pH}=5.6, \mathrm{EC}=0.5 \mathrm{mS} / \mathrm{m}$ ) were used as permeant liquids to evaluate the effects of a range of liquids on the bentonites. The compositions of the diluted solutions were based on those required to result in values of swell index (SI) corresponding to 75,50 , and $25 \%$ of the maximum SI value based on the use of only DW. The resulting solution compositions, designated as SI75, SI50, and SI 25, respectively, are summarized in Tab. 5. The compositions of SI75, SI50 and SI25 shown in Tab. 5 vary slightly with the type of bentonite, because the values of SI corresponding to 75,50 , and $25 \%$ of the maximum SI value varied slightly with the type of bentonite. The RMD was 
determined for each liquid used in this study (Tab. 5). As can be noticed, RMD decreases as the dilution factor increases; this is consistent with equation 1. Indeed, it is obvious that for a dilution factor $\mathrm{X}$ of a given solution, RMD will be decreased by the square root of $\mathrm{X}$.

\subsection{Chemical analysis.}

For the filter press test, the $\mathrm{pH}, \mathrm{EC}$, and chemical contents were measured on the tested dispersions and on the filtrate. The $\mathrm{pH}$ was measured with a Metrohm Heris E $250 \mathrm{pH}-$ meter standardized with buffer solutions at $\mathrm{pH} 7$ and $\mathrm{pH} 10 . \mathrm{EC}$ of the dispersions and effluents from the filter press tests and oedopermeameter tests were measured with a Consort $\mathrm{k} 810$ conductimeter standardized with a buffer solution at $141 \mathrm{mS} / \mathrm{m}$. Cationic concentrations were analyzed by ion chromatography System DIONEX DX 120 equipped with a warmer analytical column CS16.

\subsection{Swell index tests}

Swell index tests were performed with SL and DW following XP P 84-703 (AFNOR, 2002) which is equivalent to ASTM D 5890 (2006), whereby two grams of dried and ground bentonite are dropped into $100 \mathrm{~mL}$ of solution, and the volume occupied by the bentonite is

measured after $24 \mathrm{~h}$. A quicker, simplified methodology also was used and consisted of inserting $0.2 \mathrm{~g}$ of bentonite into $10 \mathrm{~mL}$ of solution. This procedure saves time as only a few increments are necessary to drop the bentonite in the water as compared to the standard procedures. The volume occupied by the bentonite was subsequently measured each day for $15 \mathrm{~d}$ to ensure that the equilibrium was achieved. In our case, the standard test and the simplified test provided results on the same order of magnitude (Tab. 4). Since only relative values were needed to compare results, only simplified tests were performed with SI75, SI50 and SI25.

\subsection{Filter press tests.}


For the purpose of simplicity, dispersion is defined here as a two-phase system with interactive (attractive) colloidal solid units in a low molecular liquid system as illustrated by Coussot (1997). For the filter press tests, $40 \mathrm{~g}$ of the bentonite extracted from the GCLs were dispersed in $400 \mathrm{~mL}$ of solution. Five solutions were used for each bentonite: SL, SI75, SI50, SI25 and DW. The dispersions were hydrated for $24 \mathrm{~h}$, including an initial mixing period of 3 min at 16,000 rpm with a homogenizer (IKA Ultra-Turrax T25), then allowed to set for $24 \mathrm{~h}$ at rest. Paumier et al. (2009) indicated that this procedure ensures a good homogenisation of the dispersions.

For filter press testing, an American Petroleum Institute (API) filtration cell (Baroïd) measuring $90 \mathrm{~mm}$ in diameter and $90 \mathrm{~mm}$ in height was used. At the base of the cell, Whatman filter paper with retention of 5-2.5 $\mu \mathrm{m}$ was supported by a wire mesh. The filtration cell containing $300 \mathrm{~mL}$ of bentonite dispersion was subjected to a constant pressure of 700 $\mathrm{kPa}$ by direct application of pressurised air. The applied pressure forces the filtrate through the filter paper, while retaining a cake of clay particles. The filtrate emerging from the apparatus is weighed using a balance connected to a computer to establish the relationship between the filtrate mass versus time. The filtrate mass is converted into a filtrate volume, $\omega$, assuming a liquid density, $\rho$, equal to $1000 \mathrm{~kg}^{-3}$ (Rosin-Paumier et al. 2010). The test is stopped after one hour to maintain the cake in a saturated state. Upon filtration, the supernatant is separated from the cake by discharge.

The cake intrinsic permeability, $K\left(\mathrm{~m}^{2}\right)$, is determined using Darcy's law assuming that the permeability and the specific volume are constant throughout the filtration (Li et al., 1997; Sherwood, 1997; Pantet and Monnet, 2007). The relationship between the filtrate volume, $\omega\left(\mathrm{m}^{3}\right)$ versus square root of time is linear as follows: 


$$
\omega=\left[\frac{2 \Delta P A^{2} K}{\mu b}\right]^{0.5} t^{0.5}
$$

where $\Delta P$ is the pressure drop $(\mathrm{Pa}), A$ is the cross sectional area $\left(\mathrm{m}^{2}\right), \mu$ is the filtered liquid viscosity $\left(\mathrm{kg} \cdot \mathrm{m}^{-1} \cdot \mathrm{s}^{-1}\right), t$ is time (s), and the specific volume, $b$ (dimensionless), is defined as:

$b=\frac{c A}{\omega_{t}}$

where $\omega_{t}$ is the total, cumulative filtrate volume $\left(\mathrm{m}^{3}\right)$, and $c$ is the thickness of the cake $(\mathrm{m})$. The intrinsic permeability is related to the hydraulic conductivity, $k$, as follows:

$$
K=\frac{k \mu}{\rho g}
$$

where $\rho$ is the liquid mass density $\left(\mathrm{kg} \cdot \mathrm{m}^{-3}\right)$, and $g$ is the acceleration due to gravity $\left(\mathrm{m} . \mathrm{s}^{-2}\right)$. The permittivity of the cake, $\psi_{F P}\left(\mathrm{~s}^{-1}\right)$, is defined as follows:

$$
\psi_{\mathrm{FP}}=\frac{k}{c}
$$

Combination of Eqs 2, 3, 4 and 5 results in the following correlation between $\omega$ and $t^{0.5}$ :

$$
\omega=\left[\psi_{\mathrm{FP}} \frac{2 \Delta P A \omega_{t}}{\rho g}\right]^{0.5} t^{0.5}=a t^{0.5}
$$


The parameter, $a$, was deduced from the slope of linear regression of the curve for filtrate volume versus square root of time according to Eq. 6. Assuming that the viscosity of the filtrate was equal to the viscosity of the water, permittivity $\psi_{F P}$ then was determined. Samples were tested in duplicate. Each experimental curve was evaluated, and the $\psi_{F P}$ reported herein represents the average of the two values. The mean deviation of the permittivities was $5 \times 10^{-}$ ${ }^{11} \mathrm{~s}^{-1}$.

\subsection{Oedopermeameter tests}

The hydraulic conductivity values of the raw GCLs, $k_{O}\left(\mathrm{~m}^{-1} \mathrm{~s}^{-1}\right.$, were determined under a $100-\mathrm{kPa}$ total confining stress with an oedopermeameter in accordance with the procedures described in NF P 84-705 (AFNOR, 2008) and an apparatus as described in Fig. 1 of Norotte et al. (2004) and Guyonnet et al. (2005). Tests began with a saturation phase, under 10-kPa, using a 1-mM NaCl solution under a zero hydraulic head. When at least $90 \%$ of the infinite swell had been reached (determined according to NF P 84-705), the saturating liquid was replaced by SL. Three total confining stresses of $25-\mathrm{kPa}, 50-\mathrm{kPa}$, and $100-\mathrm{kPa}$ were applied in three successive stages. Each stage lasted at least one month after application of the stress, which occurred within a few minutes. At the beginning of the $25-\mathrm{kPa}$ stage, a hydraulic head was applied to the sample, starting with $0.3 \mathrm{~m}$ maintained for approximately one week, then $0.6 \mathrm{~m}$ for one week, and finally $1.2 \mathrm{~m}$. The hydraulic head was kept at $1.2 \mathrm{~m}$ during the last two confining pressure stages.

As far as possible, the tests were not terminated before the following criteria were achieved (Shackelford et al., 1999; ASTM, 2002; Kolstad et al., 2004a; Jo et al., 2005; Benson et al., 2008; Katsumi et al., 2008b): (1) a steady hydraulic conductivity; (2) a ratio of incremental outflow to inflow (referred to herein as the "flow ratio") of approximately unity; (3) a minimum of two pore volumes of flow (PVF) passed through the specimen; and (4) ratios of effluent-to-influent electrical conductivity $(E C)$ and $\mathrm{pH}$ (herein referred to as the 
"EC ratio" and "pH ratio") within $1.0 \pm 0.1$. In addition, some authors (e.g., Jo et al. 2005) recommend comparing the concentration of specific chemical species between the influent (i.e., permeant liquid) and effluent (e.g., $\pm 10 \%)$. Thus, the chemical compositions of the effluent and the influents were monitored during the tests using chemical analyses. Indeed, these measurements furnished information on the reactivity of the GCL in front of the permeant liquid inside the oedopermeameter cell.

Considering the aforementioned termination criteria, Benson et al. (2008) found that 6 to $8 \mathrm{PVF}$ were necessary to reach the $\mathrm{Na}^{+}$and $\mathrm{Al}^{3+}$ equilibrium for flexible-wall permeameability tests performed with GCLs. Kolstad et al. (2004a) conducted their tests beyond 15 to $20 \mathrm{PVF}$ until each of the four termination criteria previously noted were achieved. The number of PVF for the oedopermeameter tests presented in this paper ranged from 6 to 40. However, chemical equilibrium was not achieved in the tests due to time restrictions. As reported by Jo et al. (2005), test durations ranging from two to five years may be necessary to achieve chemical equilibrium in some cases, particularly those where dilute chemical solutions are used as the permeant liquid.

\section{RESULTS}

\subsection{Swell index tests}

The SI test results obtained with DW and SL are presented in Tab. 4. The SI values with DW ranged from $29 \mathrm{~mL} / 2 \mathrm{~g}$ to $36 \mathrm{~mL} / 2 \mathrm{~g}$, whereas the SI values using the SL were all less than or equal to $10 \mathrm{~mL} / 2 \mathrm{~g}$. The synthetic leachate has a pronounced effect on the swelling properties of the various bentonites, as expected.

The results of the simplified SI tests performed with the diluted solutions of the SL and the four bentonites are presented on Fig. 1. As the percentage of SL in the liquid used in the test increased from $0 \%$ to $40 \%$, the SI of the bentonites decreased gradually from 44 
$\mathrm{mL} / 2 \mathrm{~g}$ to $10 \mathrm{~mL} / 2 \mathrm{~g}$, and remained relatively constant at approximately $10 \mathrm{~mL} / 2 \mathrm{~g}$ for SL contents in the liquid greater than $40 \%$.

\subsection{Permittivity tests}

\subsubsection{The filter press tests}

The filtrate curves obtained for LX1 for each solution are shown in Fig. 2. The results for the other three bentonites (not shown) were similar to those for LX1. The mass of filtrate obtained with SL was significantly greater than that with the other liquids, which is consistent with the greater concentrations of cations in SL relative to the other liquids tested. The filtration properties of bentonite-water dispersions have been shown to be greatly affected by whether the bentonite particles are aggregated or dispersed and, if dispersed, whether the particles are flocculated or deflocculated (Kellessidis et al., 2006). The increase of filtrate mass also can be attributed to different structures in terms of aggregation of the cake inside the filter press cell resulting in a greater permittivity, but this point was not investigated.

Permittivities of the bentonite dispersions in the filter press were determined using the filtration curves for all bentonites. Results are reported in Fig. 3 according to the percentage of SL in the permeant liquid. The permittivity of the bentonite dispersion increased exponentially with increasing SL concentration in the permeant liquid. Results with LX1, LX2 and LX7 are very similar, whereas the permittivity of LX5 was slightly greater than those of the other bentonites in the tests performed with pure SL. Thus, bentonite LX5 was slightly more sensitive to contact with SL.

Results from Kolstad et al. (2004a) tend to show that a GCL containing a bentonite with a SI greater than $15 \mathrm{~mL} / 2 \mathrm{~g}$ in a given liquid generally exhibits a hydraulic conductivity lower than $5 \times 10^{-11} \mathrm{~m} / \mathrm{s}$ to the same liquid. In contrast, a GCL with a SI lower than $15 \mathrm{~mL} / 2 \mathrm{~g}$ in a given liquid may exhibited greater hydraulic conductivity. Our results are consistent with those of Kostald et al. (2004a) in that a SI greater than $15 \mathrm{~mL} / 2 \mathrm{~g}$ indicated a material with a 
permittivity lower than $10^{-8} \mathrm{~m}^{2}$, but a SI lower than $15 \mathrm{~mL} / 2 \mathrm{~g}$ corresponded to permittivities ranging from $10^{-8} \mathrm{~m}^{2}$ to $5 \times 10^{-8} \mathrm{~m}^{2}$.

The filter press test revealed contrasted impacts of the liquids on the permittivity of the bentonite dispersions. Thus, in less than two days, including both the preparation time and the testing time, the LX5 bentonite appeared to be less compatible to the containment of SL than the other bentonites.

The $E C$ measurements in the dispersions varied depending on the type of bentonite. The $E C$ values based on DW dispersions were $140 \mathrm{mS} / \mathrm{m}$ for natural sodium bentonite (LX2) and ranged from $220 \mathrm{mS} / \mathrm{m}$ to $270 \mathrm{mS} / \mathrm{m}$ for the sodium activated calcium bentonites. The $E C$ values for the SI75 dispersions generally ranged from 302 to $370 \mathrm{mS} / \mathrm{m}$ except for LX2, which was only $202 \mathrm{mS} / \mathrm{m}$. Despite the composition of the solutions, the $E C$ values of the natural sodium bentonite were lower than those for the other bentonites dispersions. The greater $E C$ values of the sodium-activated calcium bentonites arise from the addition of salts to the bentonite during the activation process.

The $\mathrm{pH}$ of the dispersions varied according to the solution used to prepare the dispersion. For dispersions in $\mathrm{DW}, \mathrm{pH}$ varied from 9.5 to 8.9 . The $\mathrm{pH}$ decreased from 9.3 to 7.5 as the percentage of SL in the solution increased from the SI75 composition to the pure SL, respectively.

Cation compositions of each filtrate from the filter press tests are reported in Tab. 6. Potential sources of cations in the effluent include the permeant liquid, the dissolution of the soluble salts, and cation exchange. The potential for crystallisation of new species was not taken into account. Fig. 4 reports the difference between the measured cation concentrations in the filtrate relative to those in the permeant liquid. A value greater than zero indicates a release of a cation from the bentonite, whereas a value lowers than zero indicates consumption of a cation within the bentonite. The sodium concentrations in the filtrate were 
higher than those in the permeant liquids for each sample and each SL concentration. For the other cations, the concentrations in the filtrate were lower than those in the permeant liquid. The measured sodium may represent both exchangeable sodium and sodium released by the dissolution of the soluble salts. For example, sodium activated calcium bentonites (Fig 4a,c,d) exhibited greater sodium concentrations in the filtrate than did the natural sodium bentonite (Fig 4b). The consumption of calcium seemed to correlate with the SL concentration. Indeed, the magnitude of cation exchange increased consistently with an increase in SL concentration in the solution. Solutions with greater SL concentration also resulted in lower $\mathrm{pH}$.

\subsubsection{Oedopermeameter Tests}

Figs. 5, 6 and 7 show the evolution of the inflow, outflow and GCL thickness during the oedopermeameter tests performed with LX2, LX5 and LX7, respectively, using SL as the permeant liquid. As LX1 was no longer available, similar data could not be obtained for LX1.

Under the 25-kPa stage, the flux through LX2 was stable between 2 and $3 \times 10^{-9}$ $\mathrm{m}^{3} / \mathrm{m}^{2} / \mathrm{s}$ (see Fig. 5) and the thickness was large $(9.7 \mathrm{~mm}$ ). Under the $50-\mathrm{kPa}$ stage, the thickness decreased to $9.5 \mathrm{~mm}$ and the flux started to increase but did not reach equilibrium. By the end of the 100-kPa stage, which lasted three months resulting in 7 PVF passed through the GCL, the flux reached $1.5 \times 10^{-8} \mathrm{~m}^{3} / \mathrm{m}^{2} / \mathrm{s}$ at steady state, and the resulting thickness of the GCL was $8 \mathrm{~mm}$.

Flux values obtained for LX5 were more erratic, as shown on Fig. 6. This variability may originate from a break of the inflow due to residual air inside the cell or clogging of the liquid feed channel by bentonite. These testing artefacts were exacerbated by the longer duration of this test (6 months). At the end of the $25-\mathrm{kPa}$ and $50-\mathrm{kPa}$ stages, the fluxes were $3 \times 10^{-9} \mathrm{~m}^{3} / \mathrm{m}^{2} / \mathrm{s}$ and $8 \times 10^{-9} \mathrm{~m}^{3} / \mathrm{m}^{2} / \mathrm{s}$, respectively, and the GCL thicknesses were $6.4 \mathrm{~mm}$ and $6.2 \mathrm{~mm}$, respectively. During the 3-month, 100-kPa stage, the inflow and outflow values were 
close to each other. At the end of this stage, the flux reached approximately $1.8 \times 10^{-8} \mathrm{~m}^{3} / \mathrm{m}^{2} / \mathrm{s}$ and the GCL thickness was $5 \mathrm{~mm}$.

Under the 25-kPa stage, the flux through LX7 was approximately $3 \times 10^{-10} \mathrm{~m}^{3} / \mathrm{m}^{2} / \mathrm{s}$ and the GCL thickness was $7 \mathrm{~mm}$ (see Fig. 7). Under the 50-kPa stage, the fluxes were erratic and the thickness decreased, but no equilibrium was reached during this stage. Under the $100-\mathrm{kPa}$ stage, the inflow and outflow values were close to each other and the flux increased significantly to reach $10^{-8} \mathrm{~m}^{3} / \mathrm{m}^{2} / \mathrm{s}$ at the end of the test. The GCL thickness decreased slightly to $6.5 \mathrm{~mm}$.

Despite the differences between the three tests in terms of GCL thickness (6.5 to 9.5 $\mathrm{mm}$ ), test duration (3 to 6-months and 6 to $40 \mathrm{PVF}$ ), the three tests reached steady-state flux under the 100-kPa stage. The fluxes at the end of the tests were very similar, between 1 and 2 $\mathrm{x} 10^{-8} \mathrm{~m}^{3} / \mathrm{m}^{2} / \mathrm{s}$. The resulting hydraulic conductivities and permittivities determined at the end of the test are presented in Tab. 7. Results obtained by Guyonnet et al. (2009) on the same GCLs permeated with a $1-\mathrm{mM} \mathrm{NaCl}$ solution under the same experimental conditions are also reported in Tab. 7 for comparison. The permittivities of LX2 and LX7 were approximately four times higher in case of permeation with SL relative to permeation with the $1-\mathrm{mM} \mathrm{NaCl}$ solution. In case of LX5, the permittivity based on permeation with SL was eight times greater than that based on permeation with the $1-\mathrm{mM} \mathrm{NaCl}$ solution. The difference in bentonite reactivity is evident from the number of pore volume of flow.

Effluents from the oedopermeameters were regularly collected and analysed. Fig. 8 shows the evolution of $E C$ and $\mathrm{pH}$ versus the number of PVF for each test. Data for LX5 were not collected at the beginning of the test. The $\mathrm{pH}$ of the effluent decreased slightly during the test. The values of $\mathrm{pH}$ were similar for the three tests and decreased from 8.9 to 7.3. The $E C$ increased during the test from 840 to $1300 \mathrm{mS} / \mathrm{m}$ for LX2, from 1190 to $1360 \mathrm{mS} / \mathrm{m}$ for LX5 test and from 1060 to $1340 \mathrm{mS} / \mathrm{m}$ for LX7. For LX2 and LX7, the EC reached equilibrium 
after 3.4 PVF. The difference between the $E C$ at the beginning of the test comes from the dilution of the soluble salts inherent within the bentonite (Shackelford et al., 1999). At the end of the test, the $E C$ value is close to the $E C$ value from SL.

Cation concentrations in the effluents are reported in Fig. 9. The composition of SL is represented by horizontal lines. The difference between SL and the effluent composition comes from the dilution of soluble salts and the cation exchange between the bentonite and SL. For each test, the sodium concentration in the effluent was significantly greater than that in SL, whereas the potassium, magnesium and calcium concentrations in the effluent were lower than those in the SL. The sodium concentration in the effluent decreased, whereas the concentration for the other cations increased.

The composition of the effluent for LX2 (Fig. 9a) changed after 4 PVF. The sodium concentration decreased abruptedly, whereas the other cations reached equilibrium. At the end of the test, the effluent composition tended to approach that of the SL, but the test duration was too short to reach the equilibrium in cations concentrations between the influent and the effluent liquids.

Despite the six-month duration of the test performed with LX5, the cation concentrations in the effluent evolved during the entire test duration (Fig. 9b). Equilibrium was reached for magnesium and potassium after 25 PVF. The ammonium concentration reached the concentration of ammonium in SL after 35 PVF. The effluent contained nearly no calcium before $10 \mathrm{PVF}$, then the calcium concentration increased linearly until 35 PVF were permeated. Finally, the calcium concentration increased abruptly at the end of the test, and exceeded the concentration in SL. The calcium discharged may have originated from the dissolution of calcium carbonate present in the bentonite. The sodium concentration progressively decreased during the test but did not reach the concentration in SL, despite the long duration of the test and the large number of PVF. 
The composition of the effluent in the test performed with LX7 (Fig. 9c) was comparable to that for the LX5 at the same number of PVF. The sodium concentration decreased progressively and did not reach equilibrium after 13 PVF. At the end of the test, the sodium concentration was almost three times greater than that in SL. At the beginning of the test, all others cation concentrations were below the detection limit. Cation concentrations increased during testing, but did not reach the concentrations in the SL by the end of the test.

For the three tests, considering the five termination criteria, only three termination criteria were achieved: (1) steady hydraulic conductivity; (2) the ratio of incremental outflow to inflow in the range 1.0 to 1.1 ; and (3) 6 to $40 \mathrm{PVF}$. The $E C$ and $\mathrm{pH}$ ratios were respectively 0.9 and 1.1 for the 3 tests such that equilibrium was approached by not quite achieved. The comparison of the cation concentrations in the influent and effluent showed that the LX5 test had reached cation equilibrium for each measured cation species except potassium. For LX2, effluent-to-influent cation concentration ratio was 1.8 for sodium, 0.2 for calcium and 0.7 for the other cations. For LX7, the cation concentration ratio was 3 for sodium, 0.2 for calcium, 0.9 for magnesium and 0.7 for ammonium and potassium. Thus, chemical equilibrium was not achieved for the tests.

\section{DISCUSSION}

The resulting permittivities from both filter press and oedopermeameter tests are different, which should not be surprising since both methods are different in all respects (i.e. the material preparation, duration and confinement of the test, permeant renewal). For example, the influent in the oedopermeameter test was renewed continuously, so that the cumulated amount of cations increased continuously during the test. As a consequence, the composition of the effluent evolved during the test to a composition similar to that of the permeant liquid by the end of the test. In contrast, the filter press test was a closed-system 
with an initial amount of cations that did not evolve during the test, such that the dispersion was not able to reach equilibrium.

Fig. 10 summarizes the permittivities obtained with the oedopermeameter and the filter press tests with $\mathrm{NaCl}$ and $\mathrm{SL}$ as the testing liquids. To compare the two tests, the permittivity ratios from oedopermeameter tests, $R_{O}$ (Eq. 7), and from filter press tests, $R_{F P}$ (Eq. 8), were calculated as follows:

$$
R_{O}=\frac{\psi_{O-S L}}{\psi_{O-N a C l}}
$$

$$
R_{F P}=\frac{\psi_{F P-S L}}{\psi_{F P-W}}
$$

where $\psi_{F P-S L}$ and $\psi_{F P-W}$ is the permittivity of the filter press cake based on SL and DW, respectively, and $\psi_{O-S L}$ and $\psi_{O-N a C l}$ is the oedopermeameter based permittivity of the GCL using SL and the 1-mM NaCl solution, respectively.

For LX2 and LX7, the $R_{O}$ values were equal to 4.3 and 3.9 respectively, whereas the $R_{F P}$ values were equal to 5.2 and 4.8 , respectively. Thus, there was a good agreement between the results obtained based on the two types of tests. According to these results, a sodium activated calcium bentonite can exhibit similar hydraulic properties as a natural sodium bentonite in contact with SL. The filter press test was sensitive enough to detect the impact of the synthetic leachate on the permittivity of the bentonite. In this case $R_{F P}$ is greater than $R_{O}$. This result can be linked to the fact that the state of equilibrium reached in the filter press test corresponds to a situation that has not yet been achieved in the oedopermeameter tests, where the chemical reaction is not as advanced as in the filter press test. This result tends to show 
that 13 PVF are insufficient to reach the equilibrium reached in the filter press tests and by extension the final equilibrium.

In contrast, for LX5, the $R_{O}$ was equal to 8.3 and the $R_{F P}$ was equal to 7.1. Since this $R_{F P}$ was greater than those for the others bentonites, LX5 was thus more sensitive to the contact with SL. Indeed, the $R_{O}$ was significantly greater than that for others tests, and greater than the $R_{F P}$. As previously explained, the filter press results do not furnish the maximum permittivity. The LX5 oedopermeameter test lasted 6 months and the chemical analysis showed a pronounced interaction between the leachate and the bentonite. In this case, the oedopermeameter test showed a greater interaction between the bentonite and the leachate than the filter press test.

The $R_{O}$ may also be compared to $R_{F P}$ as shown in Fig. 11 . The $R_{O}$ appears to increase linearly with $R_{F P}$. However, the number of experimental data is insufficient to define a correlation, such that further tests are required to confirm this trend. These results show that the effect of SL on the permittivity of the bentonite was detectable either with oedopermeameter tests or filter press tests. The filter press test furnishes a single value for dispersion at the chemical equilibrium in two days and allows for detecting differences between bentonites. Indeed, the LX5 bentonite proved to be more sensitive to the SL impact than the others. The filter press test, thus, provides a good preliminary comparison method to study the impact of several liquids on various bentonites.

The oedopermeameter test is more costly and of longer test duration, requiring an experienced operator and additional analyses to ensure compliance with the termination criteria. However, the oedopermeameter test provides three advantages: (1) the confining stress and the hydraulic head can be adapted to the specific use of the GCL; (2) the GCL is tested in an intact condition including geotextiles and bonding process; and (3) the open system allows increasing the liquid/bentonite interaction. 
Based on these results, filter press tests can be used to provide a preliminary approach to distinguish between various bentonites regarding their ability to contain a given liquid, and especially to disqualify some. However, following the selection of a material using filter press tests, oedopermeameter tests should be performed in order to test the GCL in its raw form and to validate its long-term efficiency.

The oedopermeameter tests conducted in this study included consideration of four termination criteria: (1) the hydraulic conductivity was steady; (2) the ratio of outflow to inflow was near unity; (3) the $\mathrm{pH}$ and $\mathrm{EC}$ of the effluent deviated $10 \%$ from that for the influent; and (4) more than 2 PVF had passed through the specimen. According to our results, the third criterion required test durations of at least 3 to 8 PVF. However, despite the long duration of the tests, cation equilibrium between effluent and influent was not fully achieved, such that additional research is necessary to properly define the termination criteria regarding the number of PVF necessary to reach equilibrium.

\section{CONCLUSION}

The first objective of this paper concerning the possible extension of the use of filter press tests to reveal the impact of an aggressive liquid, such as the synthetic leachate (SL) used in this study, on various bentonites was achieved. Results obtained show that the measured permittivities were consistent with the aggressiveness of the permeant liquid. The chemical analyses confirm that higher SL concentration increased consistently the extent of cation exchange. The permittivities calculated both with oedopermeameter $\left(2.11 \times 10^{-8} \mathrm{~s}^{-1}\right)$ and filter press $\left(5.6 \times 10^{-8} \mathrm{~s}^{-1}\right)$ seemed to indicate that the LX5 bentonite was more sensitive to the synthetic leachate than the other bentonites. The permittivities for other bentonites, including a natural sodium bentonite and two sodium activated calcium bentonites, were similar both with oedopermeameter tests $\left(5.7\right.$ to $\left.6.5 \times 10^{-9} \mathrm{~s}^{-1}\right)$ and filter press tests $\left(3.2\right.$ to $\left.3.5 \times 10^{-8} \mathrm{~s}^{-1}\right)$. 
Consequently, a distinction between the four bentonites using the filter press test was possible, and one bentonite could be disqualified with respect to the compatibility with SL.

The second objective concerning the ability of filter press tests to provide in a few hours an indication of the long-term results of the oedopermeameter tests performed using the bentonite with the SL solution was not achieved. The results of the oedopermeameter tests reflected an intermediate level of interaction between the LX2 and LX7 bentonites bentonite and the SL, which was similar to the results based on the filter press tests. However, a greater interaction between the bentonite and a liquid may be obtained in the oedopermeameter tests than in filter press tests provided that a sufficiently long testing time is allowed. Great care must be taken to ensure that the termination criteria are achieved for each oedopermeameter test.

In case the aim of testing is to make a preliminary distinction between bentonites as regards their containment performance, liquid filter press tests appear to be sufficient. Oedopermeameter tests should be performed when a representative permittivity of the GCL used on site is required.

\section{ACKNOWLEDGEMENTS}

This study was part of the Precodd bioreacteur research program funded by ANR.

\section{REFERENCES}

AFNOR, 2008. NF P 84-705. Geosynthetic barriers - Determination of the swelling, flow and permeability characteristics of geosysnthetic clay liners (GCL) using an oedopermeameter - Characterisation test and performance test. Association Française de Normalisation, Paris, France, 21p. 
AFNOR, 2002. XP P 84 703. Détermination de la capacité de gonflement de l'argile dans les géosynthétiques bentonitiques. Association Française de Normalisation, Paris, France, $6 \mathrm{p}$.

ASTM, 2009. Standard D 5891. Standard Test Method for Fluid Loss of Clay Component of Geosynthetic Clay Liners. ASTM International, West Conshohocken, 3 p.

ASTM, 2008. Standard D 5887. Standard test method for measurement of index flux through saturated geosynthetic clay liner specimens using a flexible wall permeameter. ASTM International, West Conshohocken, 7 p.

ASTM, 2006. Standard D 5890. Standard Test Method for Swell Index of Clay Mineral Component of Geosynthetic Clay Liners. ASTM International, West Conshohocken, 4p.

ASTM, 2003. Standard D 5084. Standard test methods for measurement of hydraulic conductivity of saturated porous materials using a flexible wall permeameter. ASTM International, West Conshohocken, $23 \mathrm{p}$.

ASTM, 2002. Standard D 6766. Standard test method for evaluation of hydraulic properties of geosynthetic clay liners permeated with potentially incompatible liquids permeameter. ASTM International, West Conshohocken, 9 p.

Alther, G., Evans, J., Fang, H., Witmer, K., 1985. Influence of inorganic permeants upon the permeability of bentonite. Hydraulic barriers in soil and rock, ASTM STP 874, West Conshohocken, 64-73.

Ashmawy, A. K., Darwish, E. H., Sotelo, N., Muhammad, N., 2002. Hydraulic performance of untreated and polymer-treated bentonite in inorganic landfill leachates. Clays and Clay Minerals 50(5), 546-552.

Benson, C.H., Wang, X., Gassner, F.W., Foo, D.C.F., 2008. Hydraulic conductivity of two geosynthetic clay liners permeated with an aluminia residue leachate. Proceedings Geoamericas, Cancun, 2-5 March 2008, 94-101. 
Bouazza, A., Zornberg, J.G., Adam, D., 2002. Geosynthetics in waste containment facilities: recent advances. Proceeding of Geosynthetics, $7^{\text {th }}$ ICG, Delmas, Gourc and Girard (eds), 445-507.

Chung, J., Daniel, D. E., 2008. Modified fluid loss test as an improved measure of hydraulic conductivity for bentonite. Geotechnical testing journal 31, 243-251.

Coussot, P., 1997. Mudflow Rheology and Dynamics, IAHR Monograph, Balkema, Rotterdam, 260 p.

Day, S. R., 1994. The compatibility of slurry cutoff wall materials with contaminated groundwater. Hydraulic conductivity and waste contaminant transport in soils, ASTM STP 1142, Daniel and Trautwein (eds.), Philadelphia, 284-299.

Egloffstein, T. A., Maubeuge, K. V., Reuter, E., 2002. Application of GCLs in contact with leachates or chemical solutions. Proceeding of Geosynthetics, $7^{\text {th }}$ ICG, Delmas, Gourc $\&$ Girard (eds), 813-818.

Egloffstein, T.A., 2001. Natural bentonites - influence of the ion exchange and partial dessication on permeability and self-healing capacity of bentonites used in GCLs. Geotextiles and Geomembranes 19, 427-444.

Egloffstein, T. A., 1997. Geosynthetic clay liners. Part six: Ion exchange. Geotechnical Fabrics Report 15(5), 38-43.

Guyonnet, D., Touze-Foltz, N., Norotte, V., Pothier, C., Didier, G., Gailhanou, H, Blanc, P., Warmont, F., 2009. Performance-based indicators for controlling geosynthetic clay liners in landfill applications. Geotextiles and Geomembranes 27, 321-331.

Guyonnet, D., Gaucher, E., Gaboriau, H., Pons, C.-H., Clinard, C., Norotte, V., Didier, G., 2005. Geosynthetic clay liner interaction with leachate: correlation between permeability, microstructure, and surface chemistry. Journal of Geotechnical and Geoenvironmental Engineering 131, 740-749. 
Henry, L. B., Filz, G. M., Davidson, R. R., 1998. Formation and properties of bentonite filter cakes. Filtration \& drainage in geotechnical and geoenvironmental engineering, Geotechnical special publication 78, ASCE, Reddy and Bonala (eds.), Reston VA, 6988.

Jo, H.Y., Benson, C.H., Shackelford, C.D., Lee, J.M., Edil, T.B., ASCE, M., 2005. Long-term hydraulic conductivity of a geosynthetic clay liner permeated with inorganic salt solutions. Journal of Geotechnical and Geoenvironmental Engineering 131, 405-417.

Jo, H.Y., Katsumi. T., Benson, C. H., Edil, T. B., 2001. Hydraulic conductivity and swelling of nonprehydrated GCLs permeated with single species salt solutions. Journal of Geotechnical and Geoenvironmental Engineering 127(7), 557-567.

Johns, D.G., Shamrock, J.S., 2009. Swell index testing of GCL bentonites with general and hazardous waste leachates. Proceeding GIGSA GeoAfrica Conference, Cape Town, South Africa, 10p.

Katsumi, T., Ishimori, H., Onikata, M., Fukagawa, R., 2008a. Long-term barrier performance of modified bentonite materials against sodium and calcium permeant solutions. Geotextiles and Geomembranes 26, 14-30.

Katsumi, T., Ishimori, H., Fukagawa, R., 2008b. Evaluating methods to modify the chemical resistance of geosynthetic clay liners. Geosynthetics in civil and environmental engineering. Proceeding $4^{\text {th }}$ Asian Regional Conference on Geosynthetics, Shanghai, China, Li, Chen and Tang (eds.), 526-531.

Kelessidis, V. C., Tsamantaki, C., Pasadakis, N., Repouskou, E., Hamilaki, E., 2006. Permeability, porosity and surface characteristics of filter cakes from water-bentonite suspensions. Proceeding $6^{\text {th }}$ International Conference on Advances in Fluid Mechanics, Skiathos, Greece, WIT Press, 10 p. 
Kjeldsen, P., Barlaz, M., Rooker, A., Baun, A., Ledin, A., Christensen, Th., 2002. Present and long-term composition of MSW landfill leachate: a review. Critical Reviews in Environmental Science and Technology 32(4), 297-336.

Kolstad, D., Benson, C., Edil, T., 2004a. Hydraulic conductivity and swell of nonprehydrated geosynthetic clay liners permeated with multispecies inorganic solutions. Journal of Geotechnical and Geoenvironmental Engineering 130, 1236-1249.

Kolstad, D., Benson, C., Edil, T., Jo, H., 2004b. Hydraulic conductivity of a dense prehydrated GCL permeated with aggressive inorganic solutions, Geosynthetics International 11, 233-240.

Lee, J.M., Shackelford, C.D., Benson, C.H., Jo, H.Y., Edil, T.B, 2005. Correlating index properties and hydraulic conductivity of geosynthetic clay liners, Journal of Geotechnical and Geoenvironmental Engineering 131(11), 1319-1329.

Li, Y., Argillier, J.F., Rosenberg, E., Durrieu, J., 1997. Static and dynamic filtration properties of aqueous suspensions of clays and electrolytes. Revue de l'Institut Français du Pétrole 52, 207-218.

MEEDDAT (Ministère de l'Ecologie, de l'Energie, du Développement durable et de l'Aménagement du territoire), 2008. Guide de recommandations pour l'évaluation de l'équivalence en étanchéité passive d'installation de stockage de déchets, Version 2, MEEDAT, Paris, France, 45 pp.

Norotte, V., Didier, G., Guyonnet, D., Gaucher, E., 2004. Evolution of GCL hydraulic performance during contact with landfill leachate. Proceeding Advances in Geosynthetic Clay Liner Technology: $2^{\text {nd }}$ Symposium, ASTM STP 1456, Mackey and von Maubeuge (eds.), ASTM International, West Conshohocken, PA., 41-52.

Pantet, A., Monnet, P., 2007. Liquid-solid transition of kaolinite suspensions, Mechanics of Materials 39, 819-833. 
Patterson, S.H., Murray, H.H., 1983. Clays, Industrial Minerals and Rocks, $5^{\text {th }}$ ed., Vol 1, Lafond (ed.), AIME New York, 585-651.

Paumier, S., Pantet, A., Monnet, P., Touze-Foltz, N., 2009. Evaluation of the viscoelastoplastic properties of a clay material using a flow curve. Applied Rheology, $19,23824$.

Petrov, R.J., Rowe, R.K., 1997. Geosynthetic clay liner-chemical compatibility by hydraulic conductivity testing: factors impacting its performance. Canadian Geotechnical Journal 34(6), 863-885.

Petrov, R.J., Rowe, R.K., Quigley, R.M., 1997a. Comparison of laboratory measured GCL hydraulic conductivity based on three permeameter types. American Society for Testing and Materials, Geotechnical Testing Journal 20(1), 49-62.

Petrov, R.J. Rowe, R.K. and Quigley, R.M. 1997b)). Selected factors influencing GCL hydraulic conductivity," ASCE Journal of Geotechnical and Geoenvironmental Engineering 123(8), 683-695.

Quaranta, J., Gabr, M., Bowders, J., 1997. First-exposure performance of the bentonite component of a GCL in a low-pH calcium enriched environment. Testing and acceptance criteria for geosynthetic clay liners. ASTM STP 1308, 162-177.

Rauen, T.L., Benson, C.H., 2008. Hydraulic conductivity of a geosynthteic clay liner permeated with leachate from a landfill with leachate recirculation. Proceedings Geoamericas, Cancun, IFAI Publishers, 76-83.

Rosin-Paumier, S., Touze-Foltz, N., Pantet, A., Monnet, P., Didier, G., Guyonnet, D., Norotte, V., 2010. Swell index, oedopermeametric, filter press and rheometric tests for identifying the qualification of bentonites used in GCLs. Geosynthetics International 17, $1-11$. 
Ruhl, J. L., Daniel, D. E., 1997. Geosynthetic clay liners permeated with chemical solutions and leachates. Journal of Geotechnical and Geoenvironmental Engineering 123(4), 369381.

Shackelford, C.D., Sevick, G.W., Eykholt, G.R., 2010. Hydraulic conductivity of geosynthetic clay liners to tailings impoundment solutions. Geotextiles and Geomembranes, 28(2), 149-162

Shackelford, C.D., Benson, C.H., Katsumi, T., Edil, T.B., Lin, L., 2000. Evaluating the hydraulic conductivity of GCLs permeated with non-standard liquids. Geotextiles and Geomembranes 18, 133-161.

Shackelford, C., Malusis, D., Majeski, M., and Stern, R., 1999. Electrical conductivity breakthrough curves. Journal of Geotechnical and Geoenvironmental Engineering 125, $260-270$.

Shan, H.Y., Daniel, D.E., 1991. Results of laboratory tests on a geotextile/bentonite liner material. Proceedings Geosynthetics, Saint-Paul, USA, IFAI Publishers, 2, 517-535.

Shan, H.Y., Lai, Y.J., 2002. Effect of hydrating liquid on the hydraulic properties of geosynthetic clay liners. Geotextiles and Geomembranes 20, 19-38.

Sherwood, J.D., 1997. Initial and final stages of compressible filter cake compaction. AIChE Journal 43, 1488-1493.

Touze-Foltz, N., Lupo, J., Barroso, M., 2008. Geoenvironmental applications of geosynthetics. Keynote lecture, Proceedings EuroGeo 4, Edinburgh, UK, IGS Pub., UK, 98p.

Van Olphen, H., 1977. An introduction to clay colloid chemistry for clay technologists geologists and soil scientists. $2^{\text {nd }}$ edition, Wiley, New York, 318p. 
Vasko, S., Jo, H.Y., Benson, C.H., Edil, T.B., Katsumi, T., 2001. Hydraulic conductivity of partially prehydrated geosynthetic clay liners permeated with aqueous calcium chloride solutions. Proceedings Geosynthetics, Portland USA, IFAI Publishers, 1, 685-699.

Von Maubeuge, K., 2002. Investigation of bentonite requirements for geosynthetic clay barriers. Proceedings Clay Geosynthetics Barriers, Zanzinger, Koerner \& Gartung (Eds.), 155-163. 
Tab. 1: Some characteristics of the tested bentonites (modified from Guyonnet et al., 2009).

\begin{tabular}{|c|c|c|c|c|c|c|c|}
\hline \multirow{2}{*}{$\begin{array}{c}\text { GCL } \\
\text { Designation }\end{array}$} & \multirow{2}{*}{$\begin{array}{l}\text { Clay content by } \\
\text { mineralogy }(\%)\end{array}$} & \multirow{2}{*}{$\begin{array}{c}\text { CEC } \\
\text { meq } 100 g^{-1}\end{array}$} & \multicolumn{5}{|c|}{$\begin{array}{c}\text { Extractible cation composition } \\
\text { (\% total measured cations) }\end{array}$} \\
\hline & & & $\mathrm{Ca}^{2+}$ & $\mathrm{K}^{+}$ & $\mathrm{Mg}^{2+}$ & $\mathrm{Na}^{+}$ & $\Sigma$ \\
\hline LX1 & 76.5 & 75 & 9.9 & 0.7 & 10.1 & 79.3 & 100 \\
\hline LX2 & 68.8 & 66 & 27.5 & 1.2 & 6.2 & 65.1 & 100 \\
\hline LX5 & 71.5 & 70 & 10.6 & 0.5 & 9.9 & 79.1 & 100.1 \\
\hline LX5 & 71.5 & 70 & 10.6 & 0.5 & 9.9 & 79.1 & 100.1 \\
\hline
\end{tabular}


Tab. 2: Salt concentrations used to generate the synthetic leachate.

\begin{tabular}{|c|c|}
\hline Salt & $\begin{array}{c}\text { Concentration } \\
(\mathrm{M})\end{array}$ \\
\hline $\mathrm{Ca}(\mathrm{OH})_{2}$ & 0.007 \\
$\mathrm{CaCl}_{2}$ & 0.019 \\
$\mathrm{MgCl}_{2} 6\left(\mathrm{H}_{2} \mathrm{O}\right)$ & 0.010 \\
$\mathrm{KOH}$ & 0.017 \\
$\mathrm{NH}_{4} \mathrm{Cl}$ & 0.040 \\
$\mathrm{MgSO}_{4} 7\left(\mathrm{H}_{2} \mathrm{O}\right)$ & 0.005 \\
$\mathrm{CH}_{3} \mathrm{COOH}$ & 0.030 \\
$\mathrm{CH}_{3} \mathrm{COONa}$ & 0.030 \\
\hline
\end{tabular}


Tab. 3: Composition of the synthetic leachate.

\begin{tabular}{|c|c|}
\hline $\begin{array}{c}\text { Chemical } \\
\text { constituent }\end{array}$ & $\begin{array}{c}\text { Measured } \\
\text { value }\end{array}$ \\
\hline $\mathrm{Ca}^{2+}$ & $1042 \mathrm{mg} / \mathrm{L}$ \\
$\mathrm{K}^{+}$ & $665 \mathrm{mg} / \mathrm{L}$ \\
$\mathrm{Mg}^{2+}$ & $365 \mathrm{mg} / \mathrm{L}$ \\
$\mathrm{Na}^{+}$ & $690 \mathrm{mg} / \mathrm{L}$ \\
$\mathrm{NH}_{4}{ }^{+}$ & $720 \mathrm{mg} / \mathrm{L}$ \\
$\mathrm{Cl}^{-}$ & $3474 \mathrm{mg} / \mathrm{L}$ \\
$\mathrm{SO}_{4}{ }^{2-}$ & $480 \mathrm{mg} / \mathrm{L}$ \\
\hline $\mathrm{pH}$ & 7.1 \\
\hline $\mathrm{EC}$ & $1330 \mathrm{mS} / \mathrm{m}$ \\
\hline
\end{tabular}


Tab. 4: Standard swell index (ASTM D 5890) and simplified swell index of bentonite from four GCLs in deionised water (DW) and synthetic leachate (SL).

\begin{tabular}{|c|c|c|c|c|}
\cline { 2 - 5 } \multicolumn{1}{c|}{} & \multicolumn{2}{c|}{$\begin{array}{c}\text { Standard swell index } \\
(\mathrm{mL} / 2 \mathrm{~g})\end{array}$} & \multicolumn{2}{c|}{$\begin{array}{c}\text { Simplified swell index } \\
(\mathrm{mL} / 2 \mathrm{~g})\end{array}$} \\
\hline Bentonite & DW (1 d) & SL (1 d) & DW (15 d) & SL (15 d) \\
\hline LX1 & 34 & $<10$ & 44 & 6 \\
LX2 & 36 & 10 & 36 & 8 \\
LX5 & 29 & $<10$ & 28 & 3 \\
LX7 & 31 & $<10$ & 34 & 7 \\
\hline
\end{tabular}


Tab. 5: Compositions of solutions of the pure synthetic leachate (SL) diluted with deionised water (DW) required to produce 75,50 , and $25 \%$ of the maximum swell index (SI) as a function of the GCL bentonite.

\begin{tabular}{|c|c|c|c|c|}
\hline $\begin{array}{c}\text { Chemical } \\
\text { Solution }\end{array}$ & $\begin{array}{c}\text { GCL } \\
\text { Bentonite }\end{array}$ & $\begin{array}{c}\text { \% by vol. } \\
\text { of SL }\end{array}$ & $\begin{array}{c}\text { \% by vol. } \\
\text { of DW }\end{array}$ & $\begin{array}{c}R M D \\
\left(\mathrm{mM}^{1 / 2}\right)\end{array}$ \\
\hline \multirow{4}{*}{ SI75 } & LX1 & 10 & 90 & 0.14 \\
\cline { 2 - 5 } & LX2 & 11 & 89 & 0.14 \\
\cline { 2 - 5 } & LX5 & 11 & 89 & 0.14 \\
\cline { 2 - 5 } & LX7 & 13 & 87 & 0.15 \\
\hline \multirow{4}{*}{ SI50 } & LX1 & 21 & 79 & 0.20 \\
\cline { 2 - 5 } & LX2 & 23 & 77 & 0.21 \\
\cline { 2 - 5 } & LX5 & 21 & 79 & 0.20 \\
\cline { 2 - 5 } & LX7 & 26 & 74 & 0.22 \\
\hline \multirow{4}{*}{ SI25 } & LX1 & 51 & 49 & 0.31 \\
\cline { 2 - 5 } & LX2 & 57 & 43 & 0.32 \\
\cline { 2 - 5 } & LX5 & 47 & 53 & 0.29 \\
\cline { 2 - 5 } & LX7 & 61 & 39 & 0.34 \\
\hline
\end{tabular}

${ }^{1} R M D=$ ratio of monovalent-to-divalent cations 
Tab. 6: $\mathrm{pH}$, electrical conductivity $(E C)$ and cation concentrations in the filtrate at the end of each filter press test performed on four GCL bentonites (LX1, LX2, LX5 and LX7) dispersed in the five solutions (deionised water (DW), SI75, SI50, SI25 and SL as defined in Tab. 4).

\begin{tabular}{|c|c|c|c|c|c|c|c|c|}
\hline \multirow{2}{*}{ نِ } & \multirow{2}{*}{$\begin{array}{l}\text { Chemical } \\
\text { Solution }\end{array}$} & \multirow{2}{*}{$\mathrm{pH}$} & \multirow{2}{*}{$\begin{array}{c}E C \\
(\mathrm{mS} / \mathrm{m})\end{array}$} & \multicolumn{5}{|c|}{ Cation Concentration $\left(\mathrm{mg} \cdot \mathrm{L}^{-1}\right)$} \\
\hline & & & & $\mathrm{Na}^{+}$ & $\mathrm{NH}_{4}^{+}$ & $\mathrm{K}^{+}$ & $\mathrm{Mg}^{2+}$ & $\mathrm{Ca}^{2+}$ \\
\hline \multirow{5}{*}{$\bar{x}$} & DW & 9.5 & 240 & 409 & 0 & 2 & 0 & 2 \\
\hline & SI75 & 9.2 & 340 & 944 & 42 & 11 & 3 & 7 \\
\hline & SI50 & 9.2 & 490 & 1235 & 79 & 31 & 8 & 15 \\
\hline & SI25 & 7.2 & 710 & 1716 & 221 & 136 & 57 & 97 \\
\hline & SL & 7.7 & 1460 & 2449 & 561 & 416 & 273 & 502 \\
\hline \multirow{5}{*}{$\underset{1}{x}$} & DW & 8.9 & 90 & 180 & 8 & 3 & 0 & 1 \\
\hline & SI75 & 9.0 & 250 & 651 & 45 & 25 & 4 & 11 \\
\hline & SI50 & 8.6 & 410 & 846 & 101 & 77 & 12 & 41 \\
\hline & SI25 & 8.0 & 860 & 1344 & 323 & 292 & 105 & 331 \\
\hline & SL & 7.5 & 1390 & 1768 & 633 & 570 & 296 & 839 \\
\hline \multirow{5}{*}{2} & DW & 9.2 & 160 & 338 & 0 & 2 & 1 & 2 \\
\hline & SI75 & 9.3 & 300 & 1996 & 42 & 9 & 3 & 6 \\
\hline & SI50 & 8.6 & 450 & 1706 & 76 & 27 & 8 & 15 \\
\hline & SI25 & 8.2 & 780 & 1661 & 202 & 116 & 57 & 98 \\
\hline & SL & 7.8 & 1430 & 2335 & 563 & 395 & 301 & 592 \\
\hline \multirow{5}{*}{ x } & DW & 9.5 & 140 & 301 & 16 & 3 & 1 & 2 \\
\hline & SI75 & 9.2 & 310 & 1637 & 53 & 20 & 4 & 8 \\
\hline & SI50 & 8.9 & 490 & 1071 & 107 & 61 & 13 & 27 \\
\hline & SI25 & 8.1 & 940 & 1751 & 316 & 247 & 106 & 220 \\
\hline & SL & 7.7 & 1410 & 2272 & 601 & 487 & 288 & 618 \\
\hline
\end{tabular}


Tab. 7: Hydraulic conductivity $k\left(\mathrm{~m} . \mathrm{s}^{-1}\right)$ of LX2, LX5 and LX7 GCL bentonites obtained in the oedopermeameter tests under a $100 \mathrm{kPa}$ confining stress and a hydraulic head of $1.2 \mathrm{~m}$ after the permeation of pore volumes of flow (PVF). The permeant liquid is either $\mathrm{NaCl}\left(k_{O}\right.$ $\mathrm{NaCl}$ ) (from Guyonnet et al., 2009) or a synthetic leachate $\left(k_{O-S L}\right) . \psi_{\mathrm{O}}$ are the corresponding permittivities $\left(\mathrm{s}^{-1}\right)$.

\begin{tabular}{|c|c|c|c|c|c|c|c|}
\hline \multirow{2}{*}{ GCL } & \multicolumn{3}{|c|}{ Guyonnet et al. (2009) } & \multicolumn{3}{|c|}{ This study } & $R_{o}=$ \\
\hline & $k_{\mathrm{O}-\mathrm{NaCl}}$ & $\psi \mathrm{O}-\mathrm{NaCl}$ & PVF & $k_{\mathrm{O}-\mathrm{SL}}$ & $\psi \mathrm{O}-\mathrm{SL}$ & PVF & $\begin{array}{l}\psi \text { O-SL/ } \\
\psi \text { O-NaCl }\end{array}$ \\
\hline LX2 & $1.2 \times 10^{-11}$ & $1.3 \times 10^{-9}$ & 2.1 & $4.6 \times 10^{-11}$ & $5.7 \times 10^{-9}$ & 6.6 & 4.4 \\
\hline LX5 & $1.9 \times 10^{-11}$ & $2.5 \times 10^{-9}$ & 3.5 & $1.1 \times 10^{-10}$ & $2.11 \times 10^{-8}$ & 40.1 & 8.4 \\
\hline LX7 & $1.1 \times 10^{-11}$ & $1.7 \times 10^{-9}$ & 2.4 & $4.5 \times 10^{-11}$ & $6.5 \times 10^{-9}$ & 13.2 & 3.8 \\
\hline
\end{tabular}




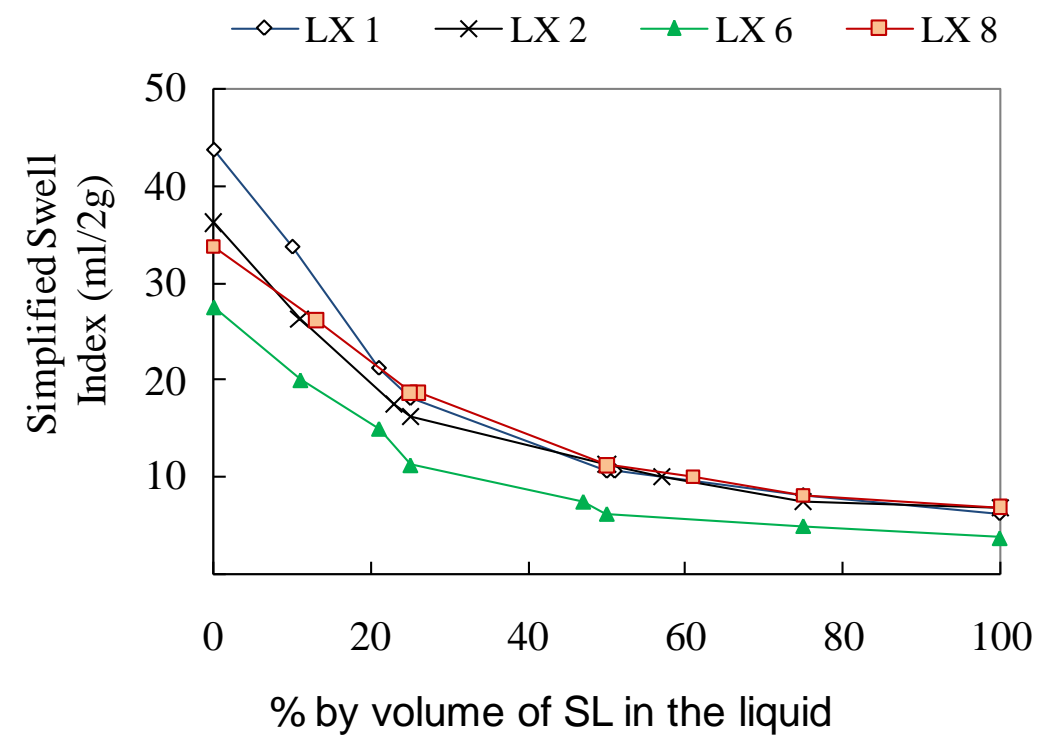

Fig. 1: Simplified swell index values obtained for each bentonite according to the percentage of synthetic leachate in the solution. 


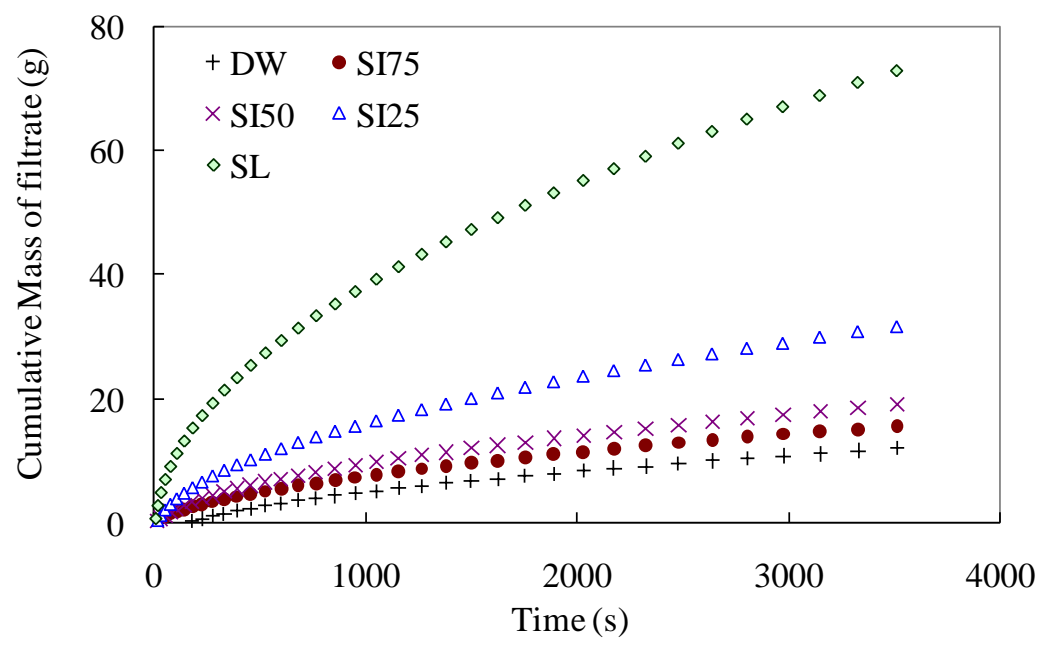

Fig. 2: Filtration curves for LX1 dispersed in various liquids. 


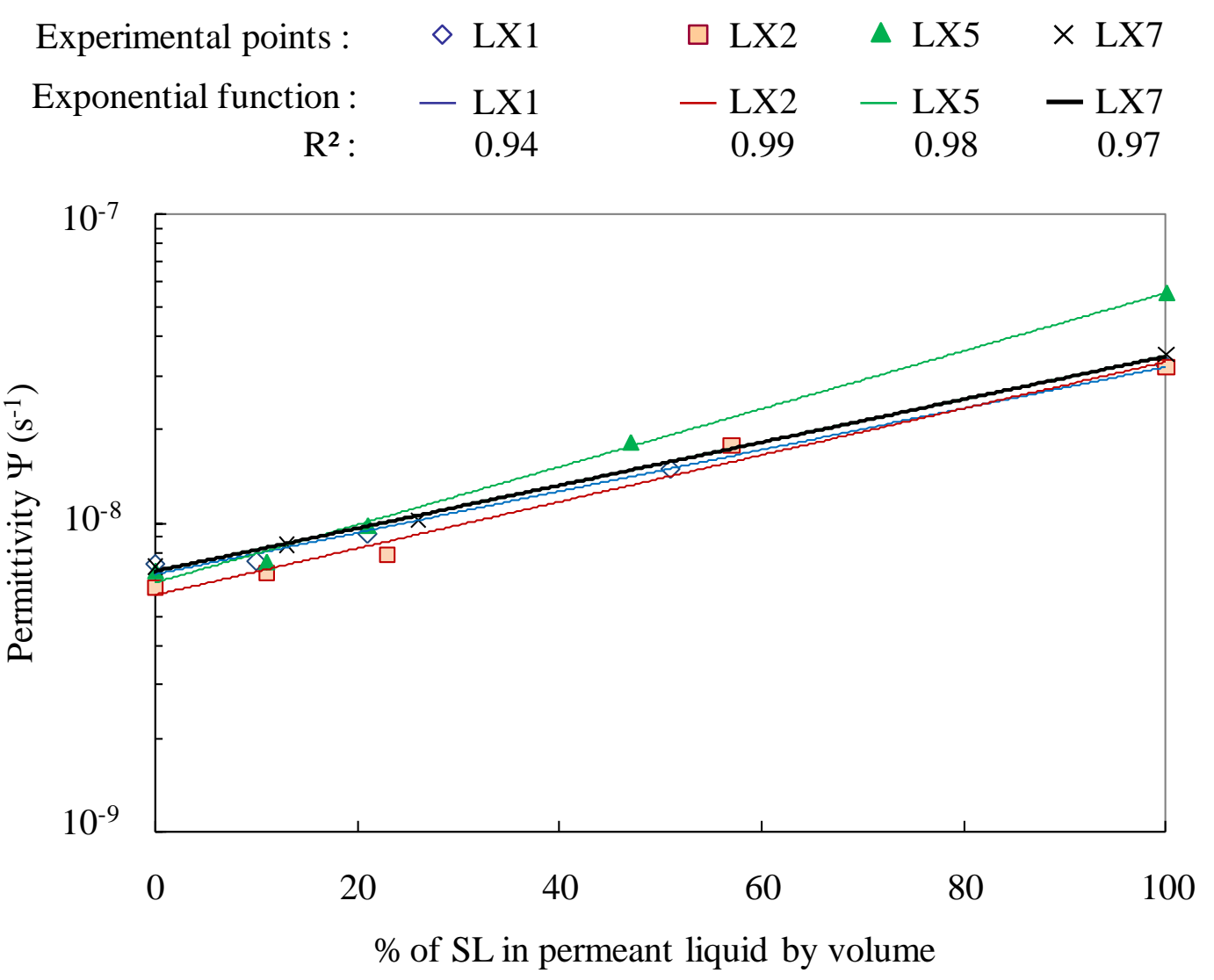

Fig. 3: Permittivities obtained with the filter press for each bentonite according to the percentage of SL in the solution. 


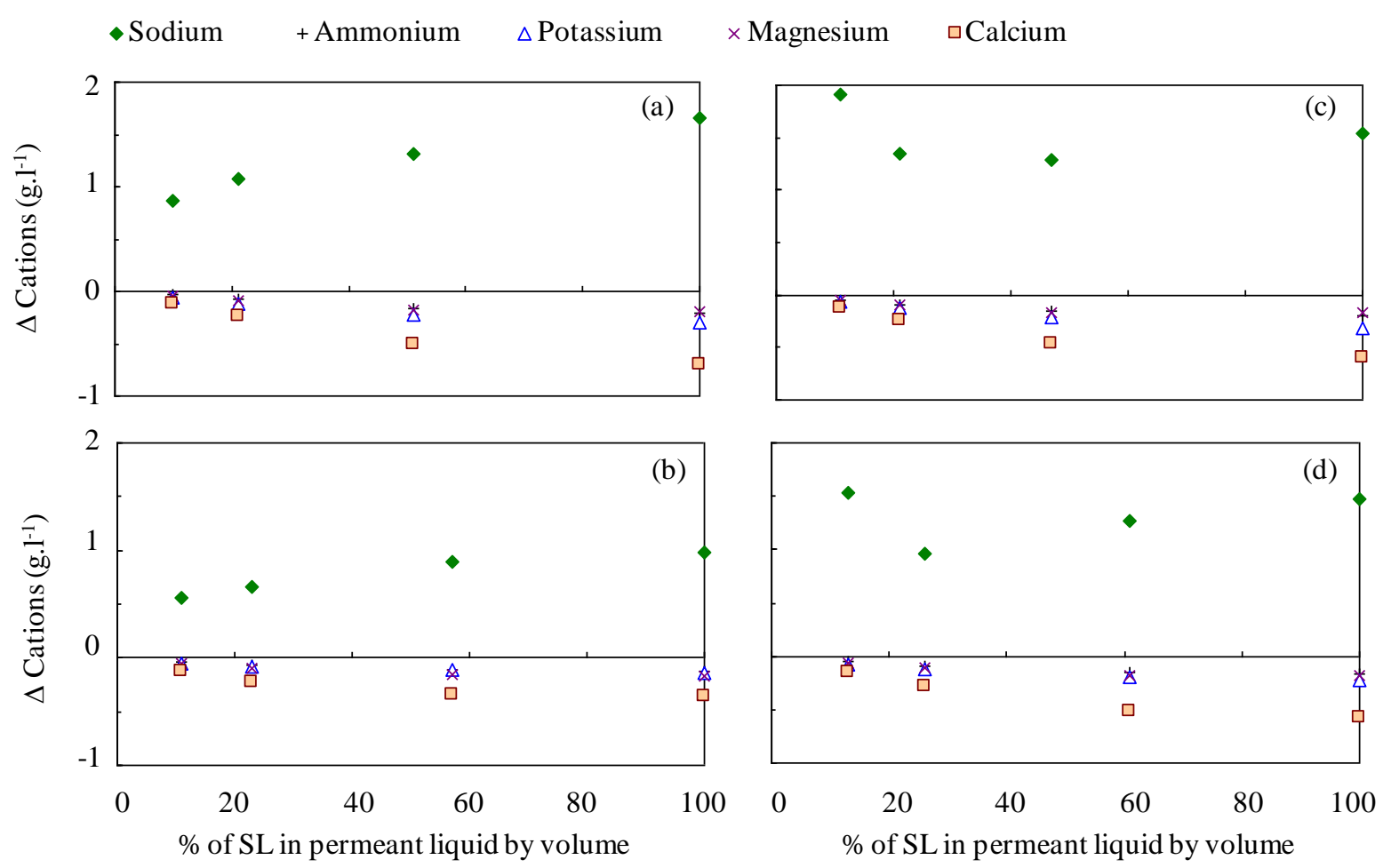

Fig. 4: Difference between the cation concentrations inside the filtrate from filter press test and the cation concentration of the solution without bentonite according to the SL content of the tested solution for four GCL bentonites: a) LX1, b) LX2, c) LX5 and d) LX7. 

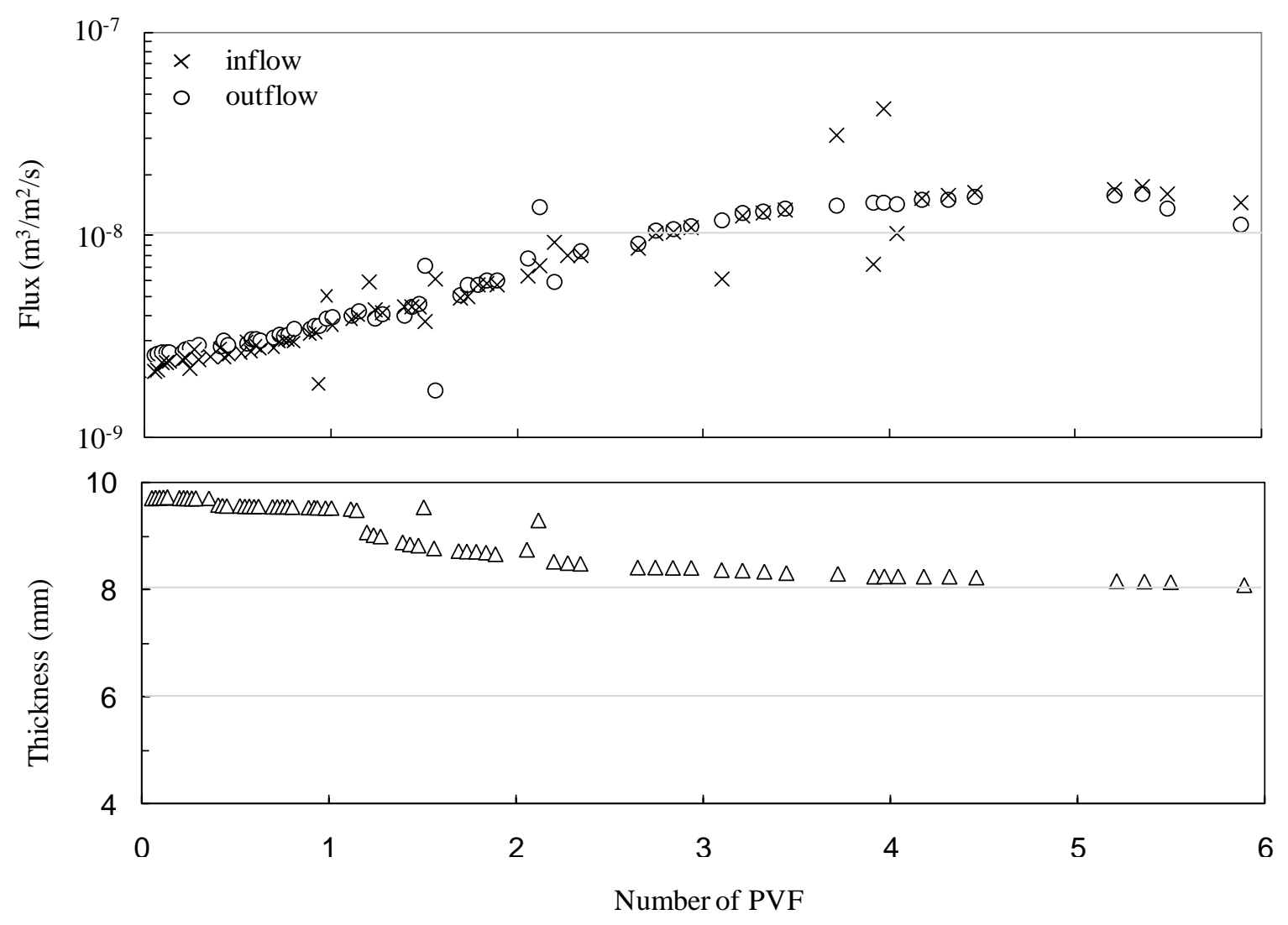

Fig. 5: Permittivity and GCL thickness of LX2 versus number of pore volume of flow (PVF) during the oedopermeameter test. 

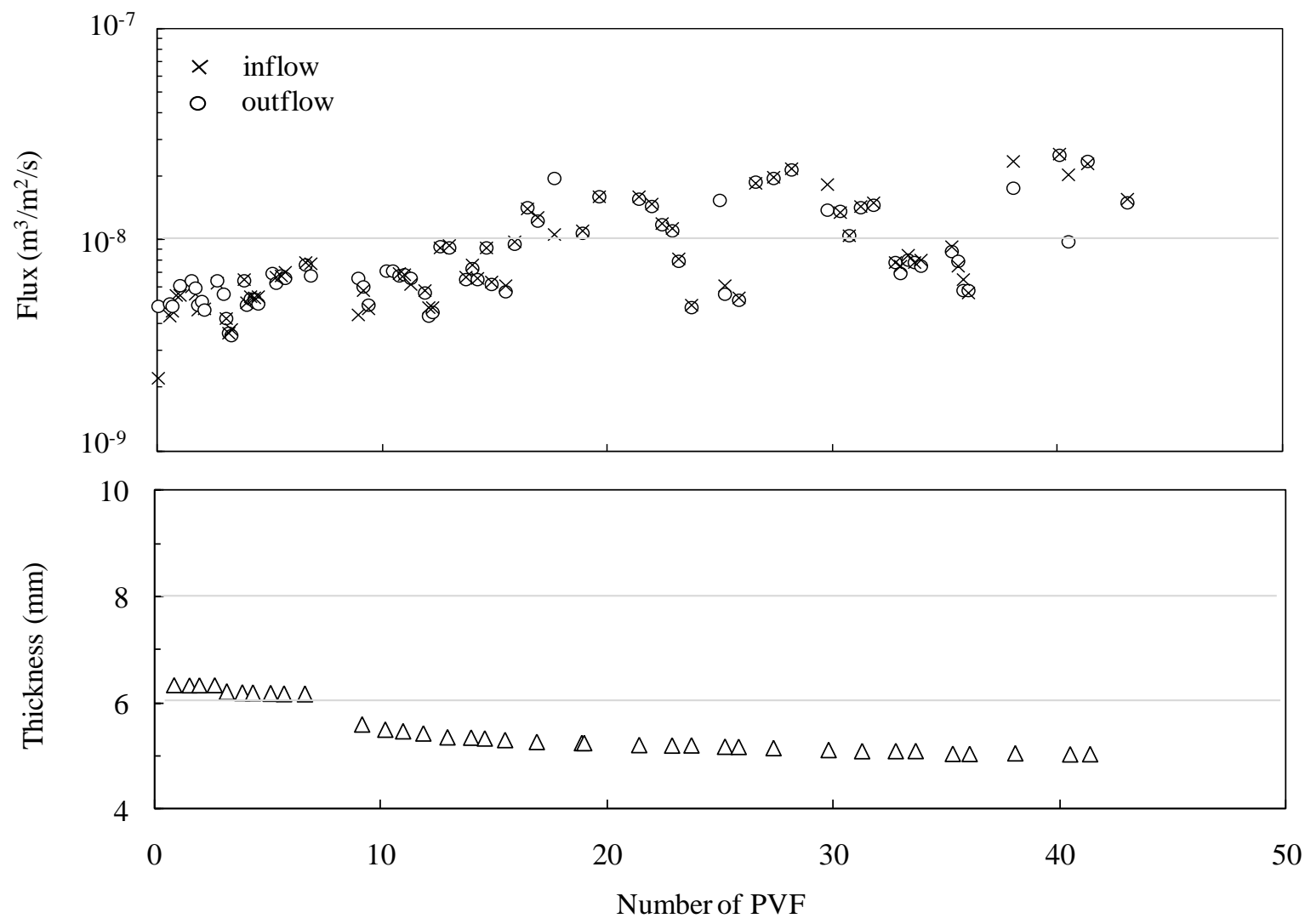

Fig. 6: Permittivity and GCL thickness of LX5 versus the number of pore volume of flow (PVF) during the oedopermeameter test. 

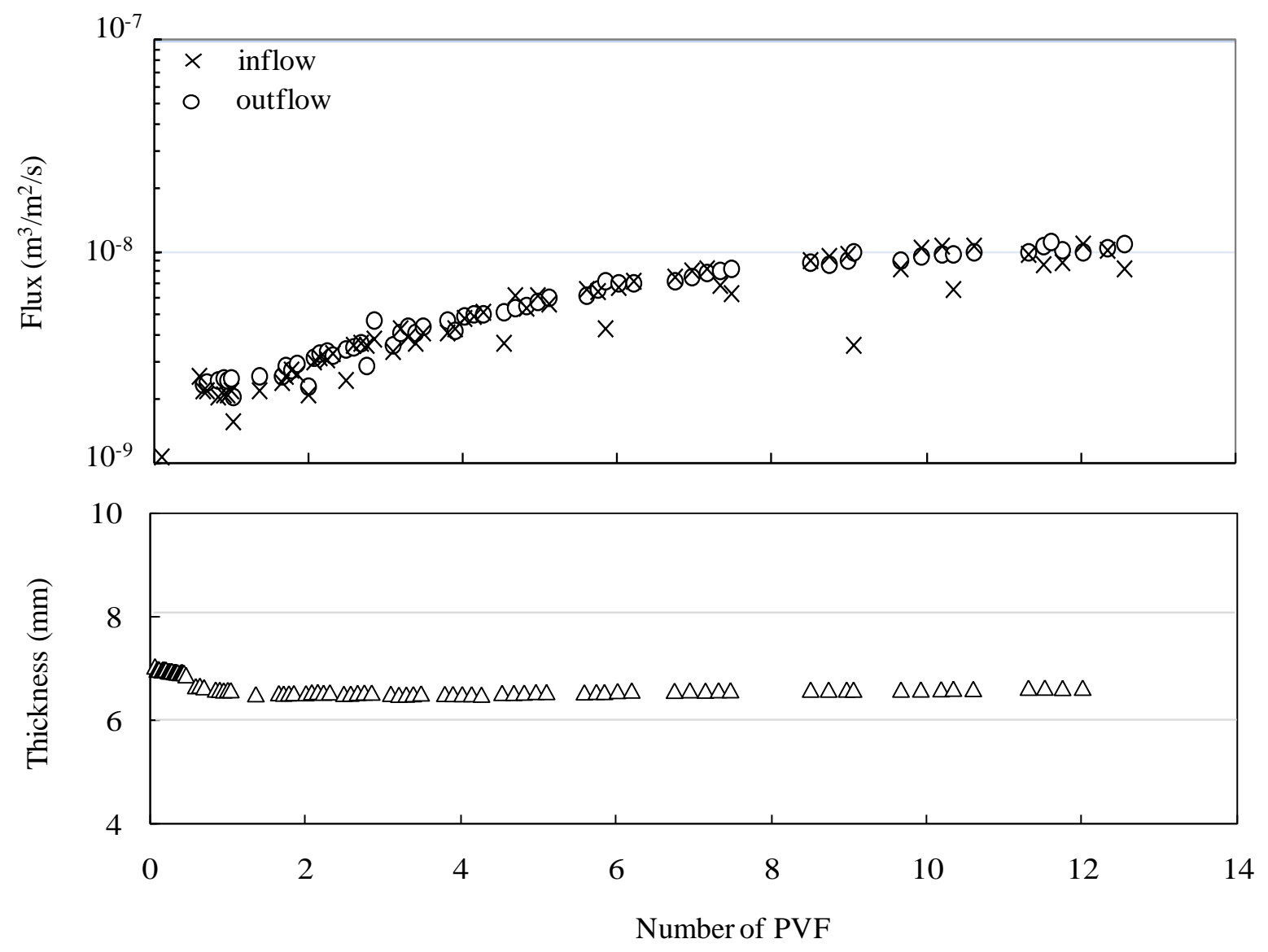

Fig. 7: Permittivity and GCL thickness of LX7 versus the number of pore volume of flow (PVF) during the oedopermeameter test. 


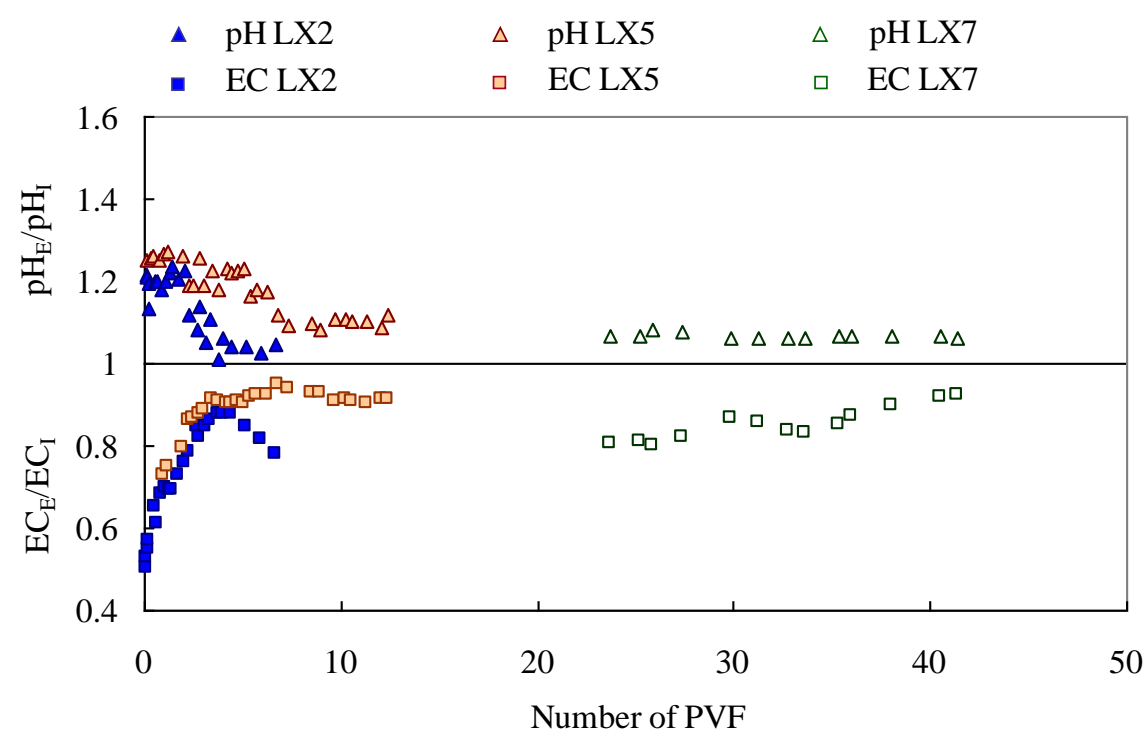

Fig. 8: Effluent-to-influent ratio of $E C$ and $\mathrm{pH}$ during the oedopermeameter tests versus the number of pore volume of flow (PVF). For LX7 test, $\mathrm{pH}$ and $E C$ measurements started at 24 PVF. 

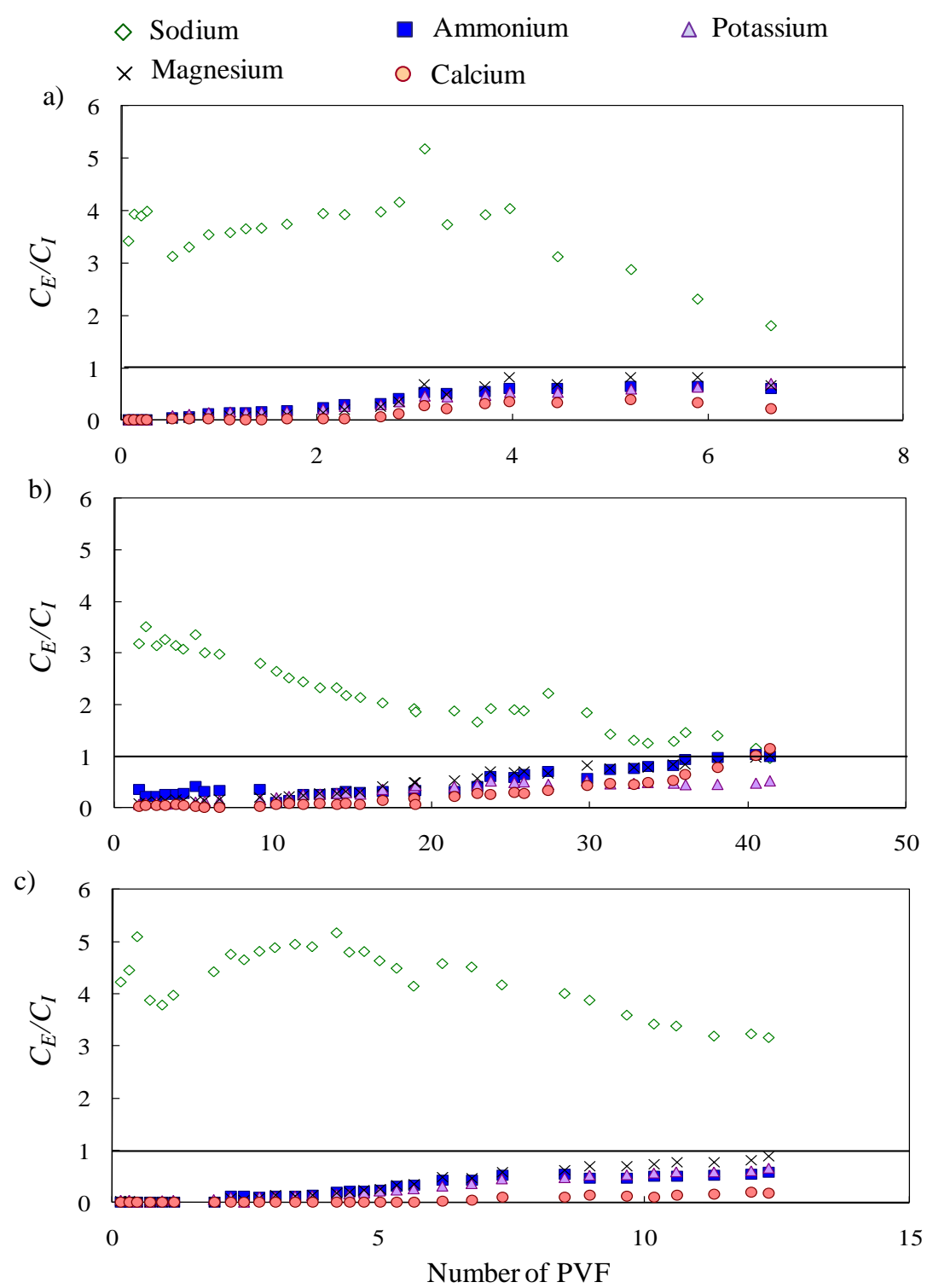

Fig. 9: Effluent-to-influent ratio of the cation concentrations $\left(C_{E} / C_{I}\right)$ in the oedopermeameter tests versus the number of pore volume of flow (PVF) for (a) LX2; (b) LX5; and (c) LX7 bentonites. The horizontal line represents the SL composition. 


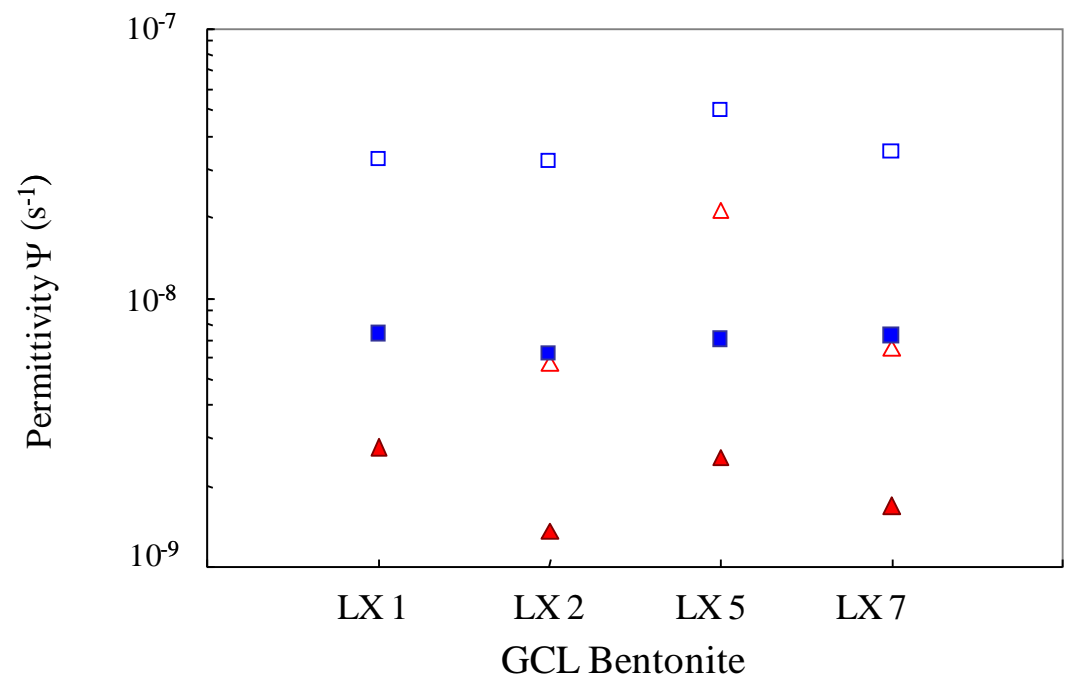

- Filter press $1 \mathrm{mM} \mathrm{NaCl}$

$\Delta$ Oedopermeameter $1 \mathrm{mM} \mathrm{NaCl}$

$\square \quad$ Filter press SL

$\triangle$ Oedopermeameter SL

Fig. 10: Comparison of the permittivities obtained with oedopermeameter and filter press tests for SL and deionised water for the four different bentonites tested in this study (LX1, LX2, LX5 and LX7). 


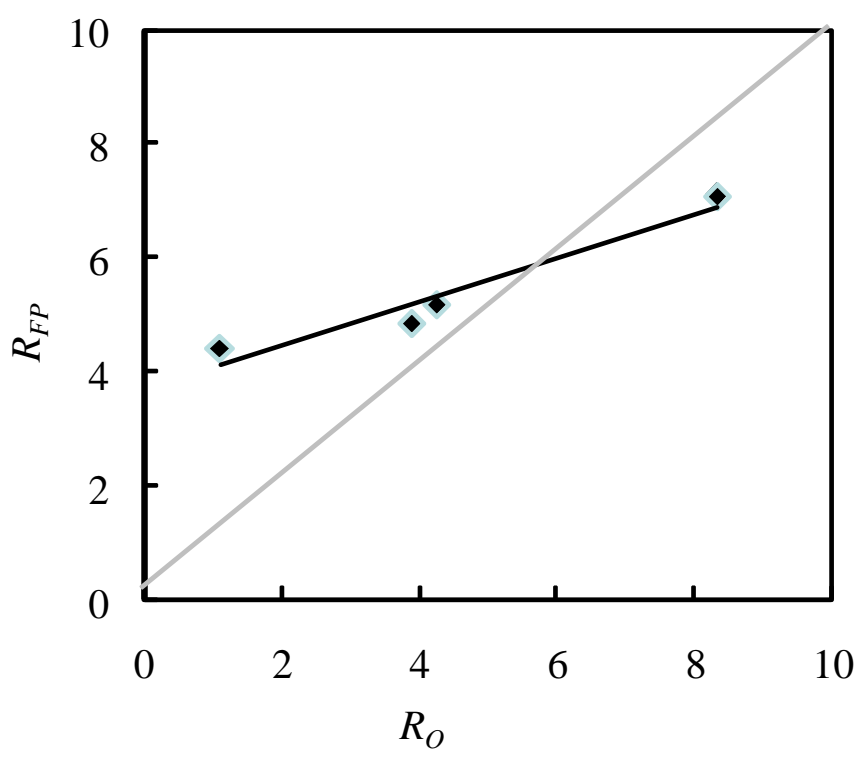

Fig. 11: Comparison graph between the permittivity ratios from oedopermeameter tests $R_{O}$ and from the filter press tests $R_{F P}$ and linear regression. 